\title{
Study the Inhibitory Effect of Streptomyces spp against the Growth some Pathogenic Bacterial
}

\author{
Bayader Abdel Mohsen, Mohsen Hashim Risan* and Asma G. Oraibi \\ College of Biotechnology, Al-Nahrain University, Iraq \\ *Corresponding author
}

\section{A B S T R A C T}

Keywords

Bacteria, actinomycetes,

Streptomyces,

antibacterial, Iraq

Article Info

Accepted:

07 November 2019

Available Online:

10 December 2019
The aimed of the study is screening of antibiotic producing Streptomyces isolates. Thirty soil samples, collected from different areas in the city of Baghdad, were screened for Streptomyces effectiveness as a source for active antibacterial, $26(86.6 \%)$ samples were suspected to contain Streptomyces, out of them, $24(80 \%)$ isolates were obtained with different morphological characteristics. Suspected Actinomycetes colonies were subcultured in ISP2 agar media carefully to obtain a pure isolate which was characterized as colored in aerial and substrate mycelium, dried, rough $\backslash$ smooth, with an irregular/regular margin; generally convex colony. The isolates were identified as Streptomyces sp. based on their morphological, physiological and biochemical characteristics. Most Streptomyces isolates were screened for their antibacterial activity against Escherichia coli and Staphylococcus aureus on malt extract yeast extract agar medium (ISP2) using a cross-streak technique.

\section{Introduction}

Actinomycetes are a group of Gram-positive bacteria with high guanine and cytosine content in their DNA (Kumari et al., 2006; Khucharoenphaisan et al., 2012; Al-Rubaye et al., 2018 a, Risan et al., 2019). The major group of Actinomycetes, Streptomyces spp. can produce an array of secondary metabolites having antibacterial or antifungal properties which applied for the human pharmaceutical use (Hughes et al., 2008). It has been reported that most of the actinomycetes are widely used in industries due to their ability to produce numerous antibiotics (Raja and Prabakarana, 2011; Al-Rubaye et al., 2018b), enzymes, vitamins, growth hormones and anti-cancerous agents (Berdy, 1995).

Streptomyces genus can also produce valuable metabolites, enzyme inhibitors commercially valuable enzymes like lipases, cellulases, 
amylase and proteases (Ravel et al., 2000). Over 600 species of Streptomyces bacteria have been described (Euzeby, 2008). As with the other Actinomyces, Streptomyces are Gram-positive, and have genomes with high guanine and cytosine content The Streptomyces are found predominantly in soil and this results in decaying vegetation (Amin et al., 2016; Risan et al., 2016; Qasim and Risan 2017). Most Streptomyces produces spores, and are noted for their distinct "earthy" odor that results from the production of a volatile metabolite, geosmin (Madigan and Martinko 2005). Streptomyces are a unique collection of prokaryotes microorganisms having diverse morphological, biochemical, cultural and physiological characters (Chavan Dilip et al., 2013).

\section{Materials and Methods}

\section{Soil samples collection}

Thirty soil samples were collected from December 2018- January 2019. Samples were collected from different areas in the city of Baghdad. The total number of soil samples and the areas for sampling selected for this study are shown in table 1 .

Different areas were used for the isolation of Streptomyces spp. from each area. The samples were taken up to a depth of 10-15 cm after removing approximately $3 \mathrm{~cm}$ of the soil surface. The samples were placed in polyethylene bags, closed tightly and stored in a refrigerator. Soil samples were incubated at $70^{\circ} \mathrm{C}$ for 2 hours to kill other microorganisms, followed by a screening procedure for the Streptomyces isolation (Korn and Kutzner, 1992; Risan et al., 2017).

\section{Isolation and identification of Streptomyces spp. from soil samples}

About one gram of dried soil samples were used to make suspension, by adding it to $99 \mathrm{ml}$ of sterile distilled water (stock suspension). The samples were shaking in a shaker at 120 rpm for 30 minutes at room temperature. Serial dilutions from $10^{-1}$ to $10^{-3}$ were made from the stock suspension and left for 10 minutes.

After shaking, $0.1 \mathrm{ml}$ of each dilution was pipetted and put on supplemented Yeast extract-malt extract agar (YEME) with Tetracycline $50 \mu \mathrm{g} / \mathrm{L}$ and Nystatin $50 \mu \mathrm{g} / \mathrm{L}$, then spread by a sterile swab to make a uniform distribution of the suspension on the surface of the media. The inoculated plates were incubated at $28^{\circ} \mathrm{C}$ for 7 to 10 days.

Based on cultural characteristics, suspected colonies of actinomycetes were selected for being characterized as small, white, and pinpoint, rough, chalky and a clear zone of inhibition around them.

The suspected colonies were subjected for their identification by types of Gram's stain, aerial and substrate mycelium color, pigment production and pigment color. The colonies were transferred from the first screening step (mixed culture) into separate agar plates and incubated at $28 \pm 1^{\circ} \mathrm{C}$ for 7 days to obtain a pure growth of actinomycetes species, the last steps were repeated several times. The pure culture was kept at $4^{\circ} \mathrm{C}$ for a further study (Oskay et al., 2004; Risan et al., 2016).

\section{Pathogenic bacteria used for antimicrobial activities}

Two isolates, including Gram positive bacteria (Staphylococcus aureus) and Gram negative bacteria (Escherichia coli) were used to determine the antibacterial activity of Streptomyces isolates (both of them isolated from urine).

These microorganisms were obtained from the College of Biotechnology/Al-Nahrain University, and activated by culturing in a 
Nutrient Broth at $37 \pm 0.1^{\circ} \mathrm{C}$ for $24 \mathrm{hrs}$ using 45 colonies. The inoculum was standardized by a turbidity standard (McFarland standard), for example $0.5 \mathrm{McFarland}=1.5 \times 10^{8} \mathrm{CFU} / \mathrm{ml}$ adjusted by the naked eye (Cockerill et al., 2012) (Table 2).

\section{Morphological characterization}

Morphological characterization was done according to the directions given for the International Streptomyces Project (ISP2). The morphological characterization of each isolate was first performed by:

\section{Colony characteristics}

Suspected Streptomyces isolates which grew on ISP 2 and GYE medium were characterized morphologically according to the colony characteristics as follows:

Mass color or mature, sporulating aerial surface growth.

The color of substrate mycelium as viewed from the reverse side.

Diffusible soluble pigments other than melanin.

Mature cultures spore mass surface was observed after 7-14 days of incubation and the color of aerial mycelium of Streptomyces was determined by a code collected by Prauser (1964) for color tabs of Baumann Farbtonkarte Atlas.

\section{Gram's stain}

A single colony was transferred by a loop to a clean glass slide. The smear was stained with crystal violet, treated with iodine, decolorized by the ethanol (95\%), and stained with safranine, then examined by a microscope (Aghighi et al., 2004).

\section{Physiological and biochemical Characterization}

The physiological and biochemical tests are important in the characterization of Streptomyces spp. following the directions given for the International Streptomyces project (ISP) (Shirling and Gottlieb, 1966; Macfadden, 2000), and some the biochemical tests described by Bergey's Manual of Systematic Bacteriology 2nd Edition Volume 2 (2005)

\section{Melanin production}

It was investigated as follows: ISP2 or ISP4 agar slants were streaked by Streptomyces spp. and incubated at $28^{\circ} \mathrm{C}$ for 7 to 10 days to detect a deep brown to black diffusible pigment (+). The absence of the color was recorded as negative (-).

\section{Carbon utilization test}

It was done by using Starch, Glycerol or dextrose as a carbon source. The preparation was done as described in the ISP2 and ISP4. ISP2 or ISP4 agar slants supplemented with indicator were streaked by Streptomyces spp. and incubated at $28^{\circ} \mathrm{C}$ for 7 to 10 days. The positive result was detected by growing the bacteria in this media and changing the color of media to pink.

\section{Citrate utilization test}

Simmon's citrate agar slants were streaked by Streptomyces spp. and incubated at $28^{\circ} \mathrm{C}$ for 7 to 10 days. The positive result was detected by changing the medium color from green to blue which indicated the Streptomyces ability to utilize citrate.

\section{Indole production test}

A loopful of Streptomyces spp. culture was inoculated in test tubes containing indole broth 
and incubated at $28^{\circ} \mathrm{C}$ for 7 to 10 days. The production of indole derivatives by the isolates was determined by the addition of Kovac's reagent. The formation of a red colored ring in the tubes indicates a positive reaction.

\section{Catalase test}

A drop of $3 \%$ hydrogen peroxide solution was added immediately on loopful with Streptomyces culture on a sterile glass slide to observe the bubbles formation which indicated the production of catalase.

\section{Antibacterial activity of Streptomyces spp.}

\section{Pathogenic bacteria used for antibacterial activity}

The pathogenic microorganisms used as reference isolates for testing the antibacterial activity. Two isolates, including Gram positive ( $S$. aureus) and Gram negative ( $E$. coli) were used to determine the antibacterial activity. The routine inoculum prepared by activation of the mentioned bacteria in a Nutrient Broth (NB) at $37 \pm 0.1^{\circ} \mathrm{C}$ for 24 hours using 4-5 colonies. The inoculum was standardized by a turbidity standard (McFarland standard), for example 0.5 McFarland $=1.5 \times 108 \mathrm{CFU} / \mathrm{ml}$ adjusted by naked eye (Cockerill et al., 2012; Risan et al., 2018).

\section{Primary screening for antimicrobial activities of Streptomyces}

Initial screen (primary screen) for antimicrobial activities were done by the cross-streak method according to Oskay, (2009) and Kumar et al., (2010), in which the isolated Streptomyces used against two different microbial pathogens. The Streptomyces were streaked as across lines in the middle of plates poured with MullerHinton agar and inoculated plates were incubated at $28^{\circ} \mathrm{C}$ for 7 days, after the Streptomyces were completely cultivated, the tested bacterial pathogens were streaked perpendicular to the Streptomyces, then plates were reincubated at $37^{\circ} \mathrm{C}$ for $24 \mathrm{hrs}$. The antimicrobial activities were observed by the naked eye in which the reference strains failed to grow near the Streptomyces line.

\section{Results and Discussion}

\section{Isolation, purification and identification of Streptomyces isolates}

Thirty soil samples, collected from different areas in the city of Baghdad, were screened for Streptomyces effectiveness as a source for active antibacterial. Actinomycetes were observed in addition to other microorganisms as mixed colonies after culturing the diluted soil sample $\left(10^{-1}\right.$ to $\left.10^{-6}\right)$ for 7-10 days on ISP2 agar. Figure 1 shows white to gray small powdery colonies suspected to be Actinomycetes isolates. In this figure, a single Actinomycete colony is shown among the mixed colonies. The single colony of Actinomycetes isolate was clearly observed in figure 2. Colonies other than Actinomycetes found within the culture may be due to the presence of their spores in the soil or they were not killed by heating. The suspected colonies were grown on ISP2 agar and selected in accordance to their color (either gray or creamy or white) with colony diameter size ranged from to $10 \mathrm{~mm}$ ) and their morphology (which have smooth surface at the beginning then became powdery, soft and granular by forming the aerial mycelium), the same results were reported by Risan et al., (2017). From 30 soil samples, 26 (86.6\%) samples were suspected to contain Streptomyces, out of them, $24(80 \%)$ isolates were obtained with different morphological characteristics. Suspected Actinomycetes colonies were sub-cultured in ISP2 agar media carefully to obtain a pure isolate which was 
characterized as colored in aerial and substrate mycelium, dried, rough $\$ smooth, with irregular/regular margin; generally convex colony. Most colonies that were isolated possess earthy odors as described by Williams et al., (1983).

\section{Selection by streaking a plate for single colonies}

As observed in figure 3, a single colony was formed by the streak plate method, to purify cultures of actinomycetes. This plating technique serially dilutes the number of bacteria in each streak, the first streak probably has a very high concentration of bacteria since it comes from a concentrated stock. By dragging a new (or freshly sterilized) tool across only one small part of the initial line, we spread a small part of the initial line out over a much larger area (the second line). This second line has less bacteria, and therefore increases the chances of seeing individual colonies. The dilution was repeated many times by streaking the entire plate from the initial concentrated streak, so somewhere on the plate a single isolated colony was picked as reported by Williams et al., (1993) and Singh and Agrawal (2003).
Identification and characterization of Streptomyces spp.

\section{Morphological characterization}

The isolates of Streptomyces were identified according to the variability in their colony morphology and microscopic characteristics like the aerial and substrate mycelium, soluble pigment, spore chain arrangement (Table 3). Some Streptomyces isolates produced diffusible pigment in the surrounding media in accordance with the aerial mycelium colour. Soluble pigment was also observed in 15 isolate. Figure 4 shows distinctive yellowish (isolate 30) series established in the Bergey's manual of determinatives bacteriology (Buchanan and Gibbons, 1974) and in the the Bergey's manual of systemic Bacteriologyl category 4. As shown in figure 5a, a colony morphology showed different Streptomyces isolates with regular edge and irregular edge. The mycelium surface is shown in some species with rough surface and smooth surface in others. The aerial mycelium colour either white, dark, pale gray or greenish gray. Substrate mycelium was either dark brown or light brown while one isolate showed a dark green figure $5 \mathrm{~b}$.

Table.1 Distribution of soil samples according to the selected areas at Baghdad city

\begin{tabular}{|c|c|c|}
\hline No & Type & Areas of study \\
\hline $\mathbf{1 5}$ & Soil samples & Al- Jadria \\
\hline $\mathbf{1 0}$ & Soil samples & Al- Qadesia Qr \\
\hline $\mathbf{5}$ & Soil samples & Al- Aamerya \\
\hline
\end{tabular}

Table.2 The source of pathogenic bacteria used for detection the antibacterail activity of Streptomyces isolates

\begin{tabular}{|c|c|c|}
\hline Source of samples & Type & Site of isolation \\
\hline \multirow{2}{*}{$\begin{array}{l}\text { Biotechnology College } \backslash \text { Al-Nahrain } \\
\text { University }\end{array}$} & Staphylococcus aureus & Urine \\
\hline & Escherichia coli & Urine \\
\hline
\end{tabular}


Table.3 Morphological characteristics of Streptomyces isolates

\begin{tabular}{|c|c|c|c|c|c|c|c|}
\hline $\begin{array}{c}\text { Isolate } \\
\text { No. }\end{array}$ & $\begin{array}{c}\text { Isolates } \\
\text { name }\end{array}$ & Colony morphology & $\begin{array}{c}\text { Arial } \\
\text { mycelium }\end{array}$ & $\begin{array}{c}\text { Substrate } \\
\text { Mycelium } \\
\text { Reverse side } \\
\text { pigments }\end{array}$ & $\begin{array}{c}\text { Mycelium } \\
\text { surface }\end{array}$ & Soluble pigment & $\begin{array}{l}\text { Spore chain } \\
\text { morphology }\end{array}$ \\
\hline 1. & B3-2 & Irregular edge-circular & Light gray & Light brown & smooth & brown & straight \\
\hline 2. & B12 & Regular edge-circular & Light gray & Light brown & smooth & Light brown & straight \\
\hline 3. & B1-3 & Irregular edge-circular & Light gray & Light brown & smooth & Light brown & straight \\
\hline 4. & B3-4 & Regular edge-circular & Light gray & Yellowish & Smooth & Yellow & straight \\
\hline 5. & B1-4 & Regular edge-circular & gray & Darck brown & Rough & No pigment & straight \\
\hline 6. & $\mathrm{~B} 18$ & Irregular edge-circular & Light gray & Darck brown & smooth & Light yellow & straight \\
\hline 7. & BT6 & Regular edge-circular & gray & brown & rough & Light brown & straight \\
\hline 8. & $\mathrm{~B} 25$ & Irregular edge-circular & White gray & Light brown & smooth & No pigment & spiral \\
\hline 9. & BT5 & Irregular edge-circular & gray & Darck brown & rough & No pigment & straight \\
\hline 10. & BH14 & Regular edge-circular & Light gray & Light brown & rough & light yellow & straight \\
\hline 11. & B1 & Regular edge-circular & Light gray & Light brown & smooth & dark & straight \\
\hline 12. & $1-3 \mathrm{C}$ & Regular circular & White gray & Brown & smooth & No pigment & spiral \\
\hline 13. & $4-3 C$ & Regular edge-circular & Light gray & Light brown & smooth & Dark yellow & straight \\
\hline 14. & B2-4 & Irregular edge-circular & gray & Light brown & smooth & No pigment & straight \\
\hline 15. & B3 & Irregular edge-circular & White gray & brown & rough & Light yellow & straight \\
\hline 16. & B21 & Regular edge-circular & gray & Light brown & smooth & No pigment & spiral \\
\hline 17. & B4-4 & Regular edge-circular & gray & brown & smooth & Light yellow & straight \\
\hline 18. & B1-4 & Regular circular & gray & brown & smooth & No pigment & rectiflexible \\
\hline 19. & B3-3 & Irregular circular & Light gray & Light brown & smooth & Dark brown & straight \\
\hline 20. & B5 & Iregular circular & gray & Brown & smooth & Light yellow & Straight \\
\hline 21. & B5-5 & Irregular circular & White & Light yellow & rough & Light yellow & straight \\
\hline 22. & BM3 & Regular & Gray & brown & smooth & No pigment & straight \\
\hline 23. & B23 & Irregular circular & White gray & Light brown & rough & Light yellow & rectiflexible \\
\hline 24. & B5-2 & regular & gray & Light brown & smooth & Light brown & straight \\
\hline
\end{tabular}

Table.4 Biochemical tests of Streptomyces spp

\begin{tabular}{|c|c|c|c|}
\hline No & Test & Reaction & Result \\
\hline $\mathbf{1 .}$ & Melanin & Black to brown & Negative \\
\hline $\mathbf{2 .}$ & Catalase & Bubbles & Positive \\
\hline $\mathbf{3 .}$ & Citrate Utilization & Deep blue color & Positive \\
\hline $\mathbf{4 .}$ & Indole production & No color zone & Negative \\
\hline $\mathbf{5 .}$ & Sugar utilization & Growth & Positive \\
\hline
\end{tabular}


Fig.1 Actinomycetes first screening in ISP2 agar from soil samples dilution $10^{-3}$ at $28^{\circ} \mathrm{C}$ for 7-10 days

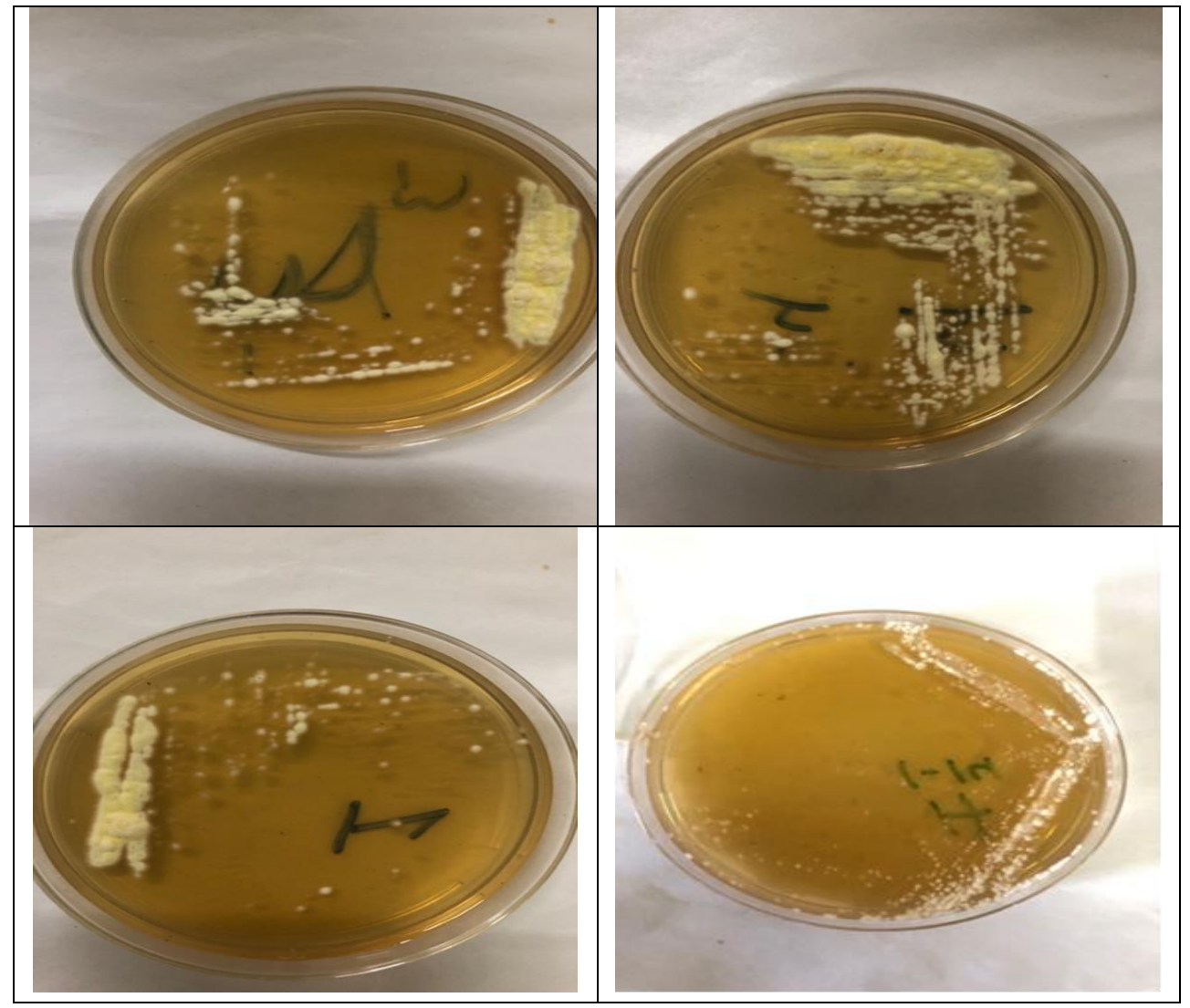

Fig.2 Colorful chalky/dusty appearance of the single Actinomycete colony

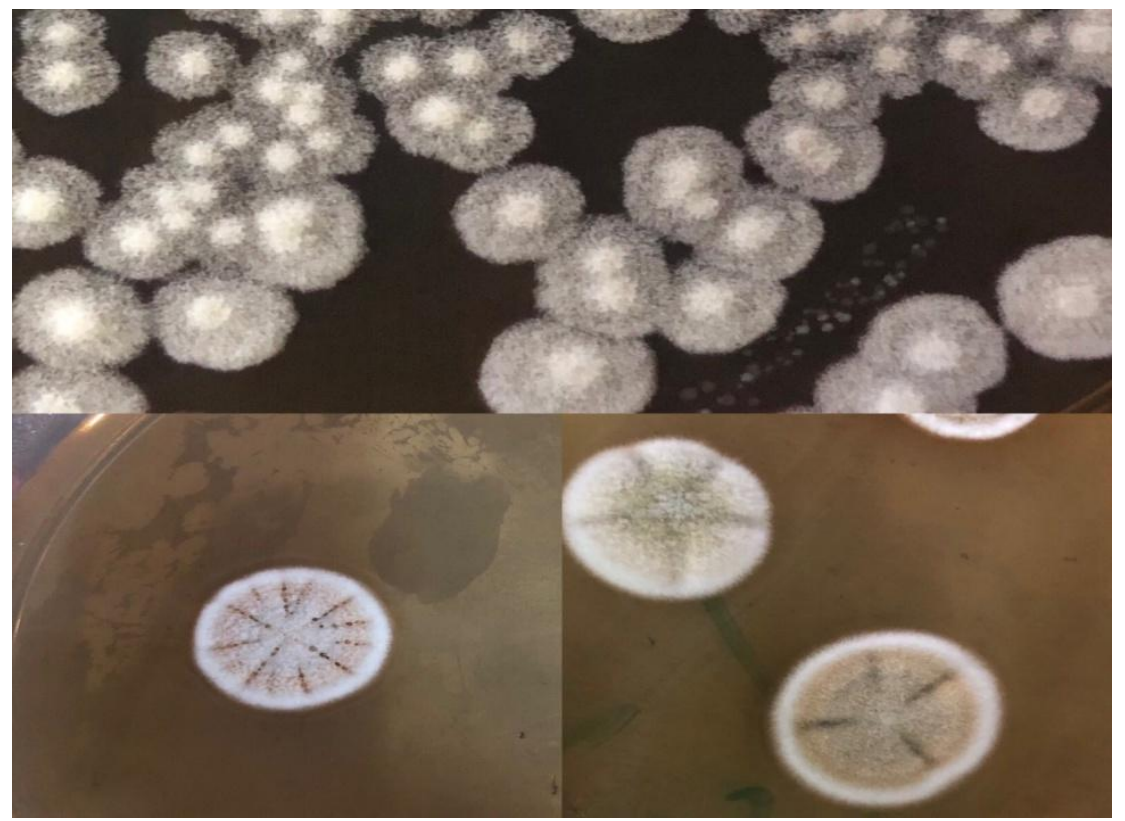


Table.5 Primary screening of antibacterial activities of Streptomyces isolated from sediment soils against $S$. aureus and $E$. coli by cross streaking method

\begin{tabular}{|c|c|c|c|}
\hline Isolates & S.aureus & E. coli & Notes \\
\hline B3-2 & + & + & \\
\hline B12 & + & + & Selected \\
\hline B1-3 & + & + & Selected \\
\hline B3-4 & + & + & Selected \\
\hline B1-4 & - & - & \\
\hline B18 & + & + & Selected \\
\hline BT6 & - & - & \\
\hline B25 & + & - & Selected \\
\hline BT5c & + & + & Selected \\
\hline BH14 & + & + & Selected \\
\hline Be1 & + & + & Selected \\
\hline $1-3 C$ & - & - & \\
\hline $4-3 C$ & - & - & \\
\hline B2-4 & + & + & Selected \\
\hline B3 & + & + & \\
\hline B21 & + & + & Selected \\
\hline B4-4 & - & - & \\
\hline B1-4 & + & + & \\
\hline B3-3 & + & + & Selected \\
\hline B5 & + & - & \\
\hline B4-3 & + & + & Selected \\
\hline BM3 & - & - & - \\
\hline B23 & - & - & - \\
\hline B5-2 & + & - & - \\
\hline & & & \\
\hline
\end{tabular}

Fig.3 Single colony formation of Streptomyces spp. cultured on ISP2 formed by streak plate method

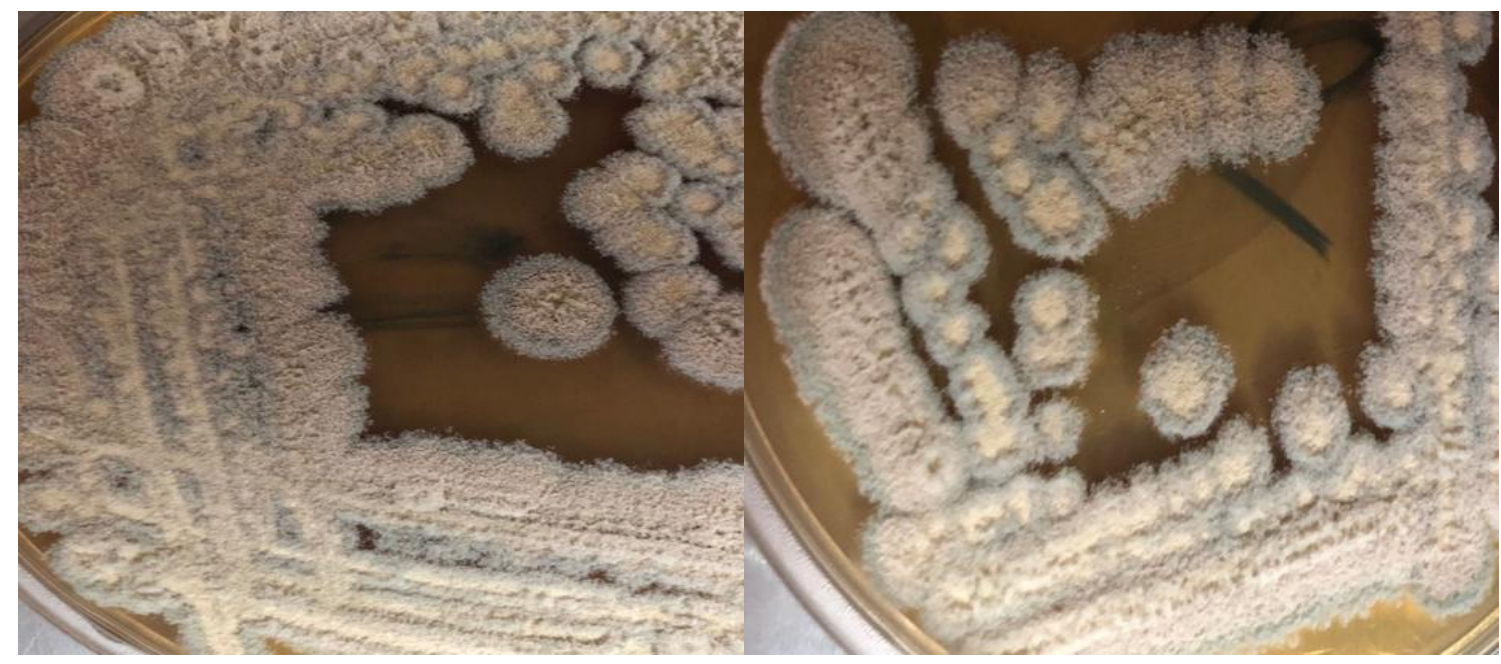


Fig.4 Streptomyces spp. cultured on glycerol yeast extract media at $28^{\circ} \mathrm{C}$ for $7-10$ days. Left isolate without pigment, Right isolate with yellow pigment
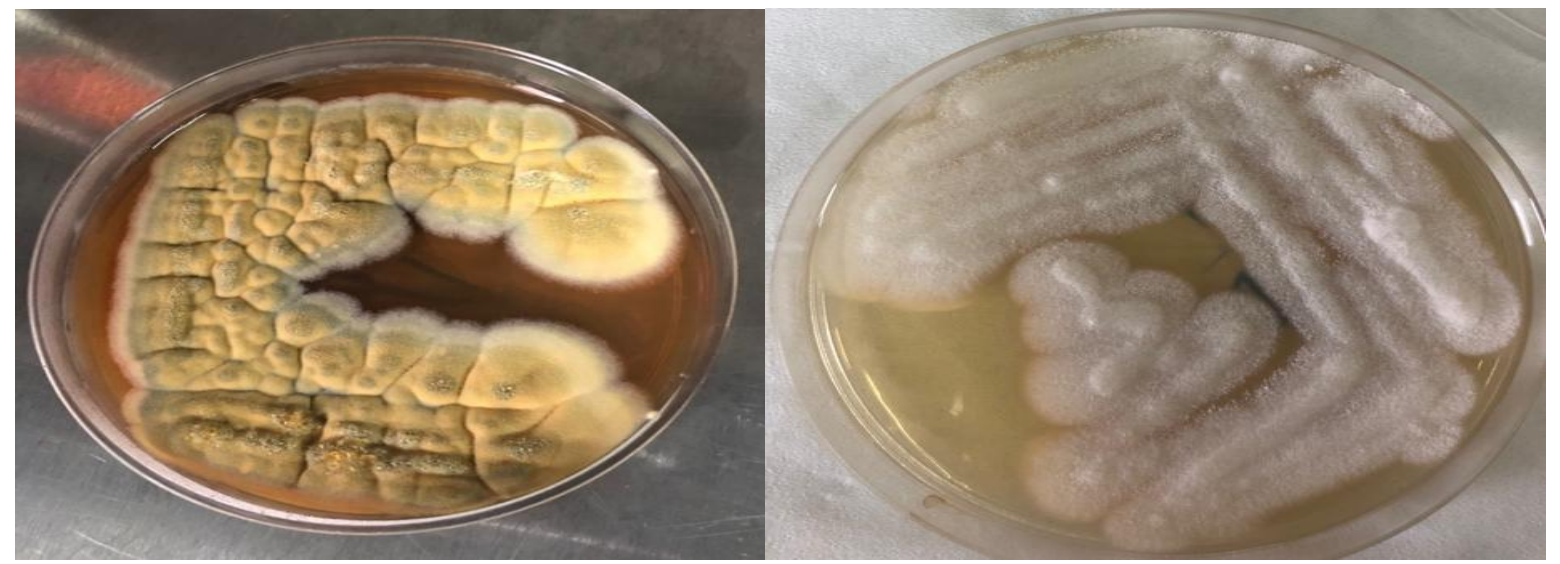

Fig.5a Arial mycelium of Streptomyces grown in ISP2 media at $28^{\circ} \mathrm{C}$ for $7-10$ days
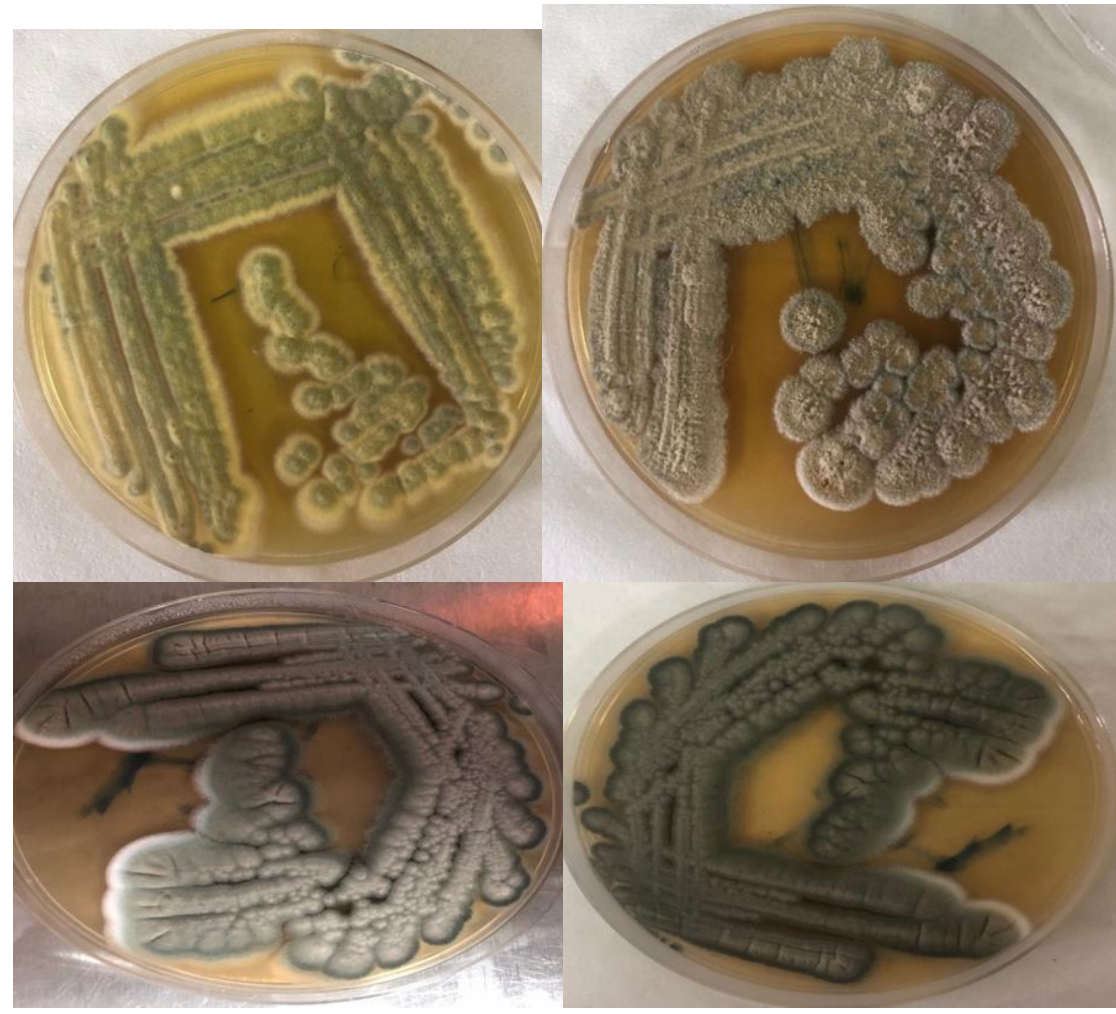
Fig.5b Substrate mycelium of Streptomyces grown in ISP2 media at $28^{\circ} \mathrm{C}$ for $7-10$ days

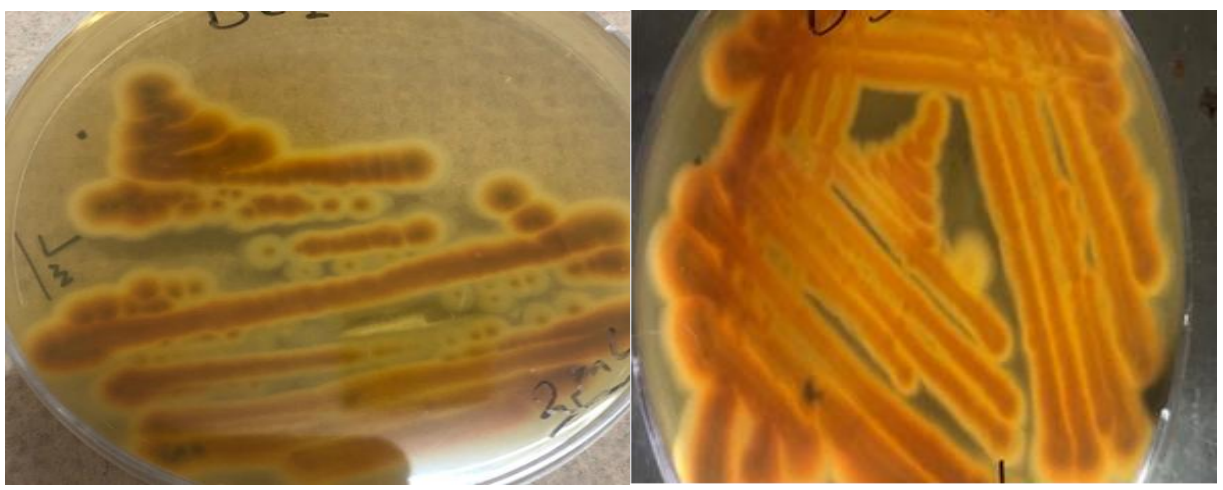

Fig.6a Antimicrobial activity of 13 Streptomyces isolates against S. aureus (Staph) and E.coli (E coli), using cross streaking method with positive result

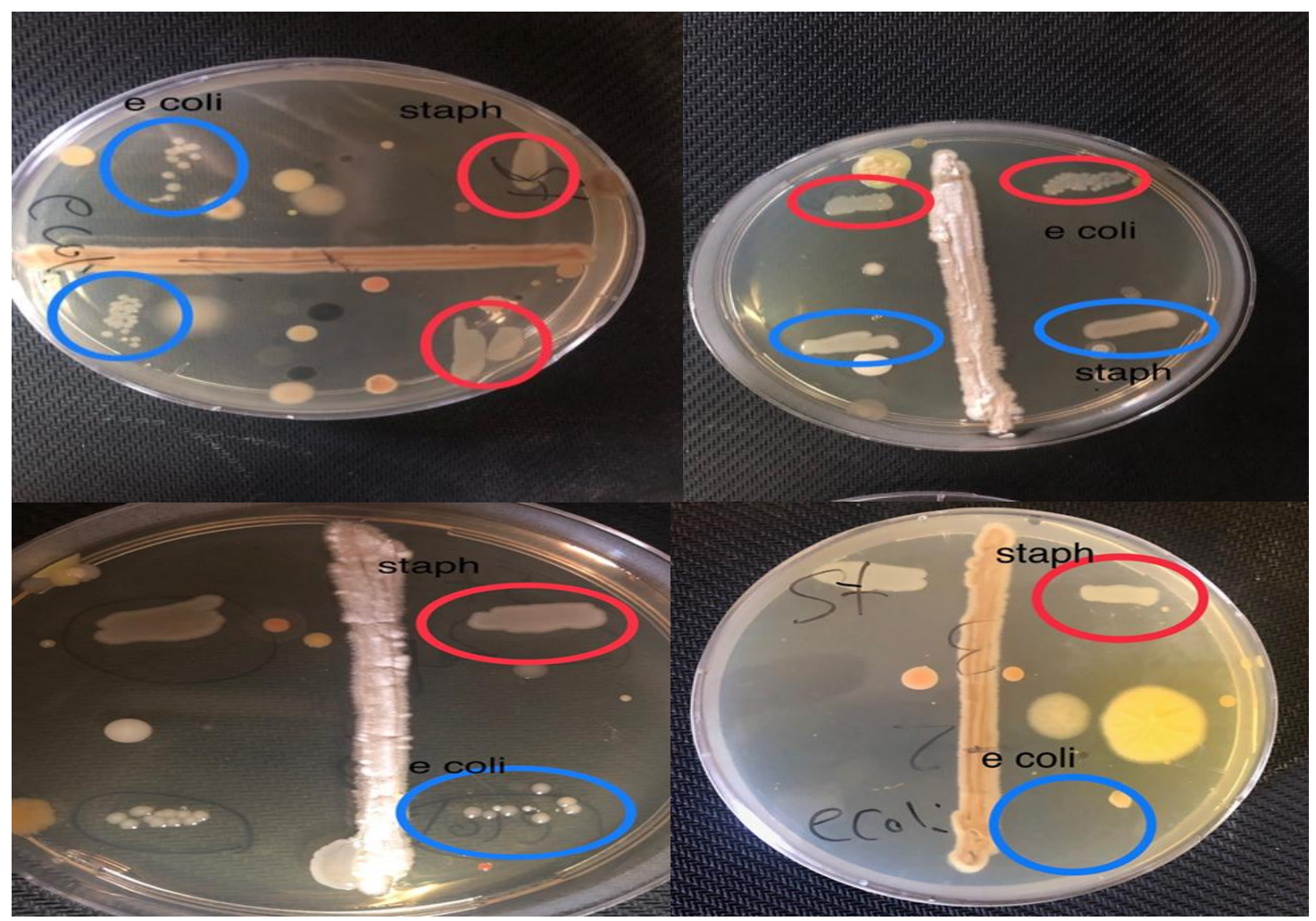


Fig.6b Antimicrobial activity of 8 Streptomyces isolates against S. aureus and E. coli, using cross streaking method with negative result

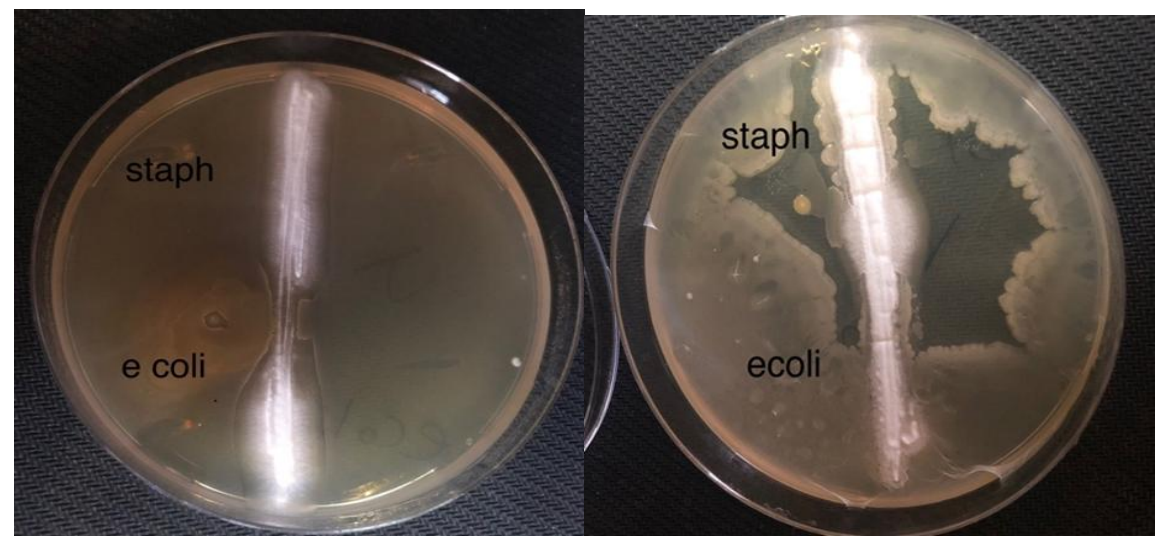

Twenty four isolates that grew on ISP2 media belong to the genus Streptomyces since colonies were slow growing, aerobic, glabours or chalky, folded. Most colonies produce D an earthy odour and they possessed aerial and substrate mycelia with different colors.

All the isolates were examined under a microscope after 7-10 days of incubation to see the hyphae. The spore chain morphology was observed after 2 weeks of incubation, showing various arrangements either straight, spiral or flexuous depending on the Streptomyces species. Most strains were with straight chain arrangement, except three strains with spiral chain arrangement and two with rectiflexible arrangement. The same results were reported by Sakiyama et al., (2014).

Streptomyces are chemoheteroorganotrophs. They make a large class of Gram positive bacteria, forming hyphae like that in fungi with a growing temperature and $\mathrm{pH}$ at $28^{\circ} \mathrm{C}$ and 8, respectively. They produce a characteristic "earthy" smell of soil by the production volatile low molecular weight compounds called geosmins. They can utilize complex organic materials in the soil and use them as sources for carbon and energy making these bacteria essential for the production of fertile soil.
Streptomyces belong to the order Actinomycetales, characterized by the formation of substrate and aerial mycelium on solid media, presence of spores. The majority of soil actinomycetes form a very important class of bacteria since they produce numerous natural products such as antibiotics and enzymes. More than $70 \%$ of the known natural antibiotics produced are from Actinomycetes (Berdy, 2005).

\section{Biochemical test}

Biochemical results of Streptomyces spp are shown in table 4. The Streptomyces have the ability to produce enzymes like catalase, gelatinase and urease. Simmon's citrate utilization was positive while indole production was negative. Sugar utilization was represented by growing of Streptomyces in media supplemented with Dextrose or starch or Glycerol as a carbon source, using the biochemical test to analyze was reported by Vijayalakshmi et al., (2011).

\section{Primary screened of Streptomyces for anti- bacterial activity}

About 24 Streptomyces isolates were obtained from 3 regions as a source of soil samples and tested for their antibacterial activities against 
E. coli and $S$. aureus using the cross streaking method. Table 5 shows a summary of the antibacterial activity of all Streptomyces isolates including the positive (+ve) result which indicates the ability of Streptomyces products to stop the growth of pathogenic bacteria, while the negative (-ve) result indicates no antibacterial activities which was neglected and was not selected for further analysis. Risan et al., (2017) showed similar results for their isolates regarding antibacterial activities. Out of 24 isolates, 16 (66.6\%) isolates showed high antibacterial activities, $13(43.3 \%)$ had antibacterial activity against both $S$. aureus and $E$. coli, while only $3(10 \%)$ isolates showed activity against S.aureus. The same results were represented by Parungao et al., (2007) who showed that the antibacterial activity of Streptomyces secondary metabolites against Gram positive bacteria are more active than Gram negative bacteria. The isolates which showed the highest antibacterial activity are represented in figure 6a, highlighted and summarized in table (5), and all were subjected to a secondary screening. While $8(1.9 \%)$ isolates showed no antibacterial activity figure $6 b$.

\section{References}

Aghighi, S., Bonjar, G. H. S., Rawashdeh, R., Batayneh, S., and Saadoun, I. (2004). First report of antifungal spectra of activity of Iranian Actinomycetes strains against Alternaria solani, Alternaria alternate, Fusarium solani, Phytophthora megasperma, Verticillium dahliaeand, Saccharomyces cerevisiae.

Al-Rubaye T ; Risan M. H. ; Al-Rubaye D; Radi O. R. (2018b). Identification and In vitro antimicrobial activities of Marine Streptomyces spp. Bacteria from Tigris River Sediments in Baghdad City. World Journal of Pharmaceutical and Life Sciences, 4(10): 120-134.

Al-Rubaye, T. S.; Risan, M. H. ; Al-Rubaye
D. and Radi O. R. (2018a). Characterization of marine Streptomyces spp. bacterial isolates from Tigris river sediments in Baghdad city with Lc-ms and 1 HNMR, Journal of Pharmacognosy and Phytochemistry 7(5): 2053-2060.

Amin S. M ; Risan M. H. , Abdulmohimin N. (2016). Antimicrobial and Antioxidant Activities of Biologically Active Extract from Locally Isolated Actinomycetes in Garmian Area, J. Garmian University, $1(10): 625-639$.

Bérdy, J. (2005). Bioactive Microbial Metabolites A Personal View. J Antibiot 58: 126 Buchanan and Gibbons., Bergey's manual of determinatives bacteriology, (1974).

ChavanDilip V.; Mulaje S. S. and Mohalkar R.Y. (2013). A review onactinomycetes and their biotechnology application. Int J Pharma Scie. Res. 4(5):1730-1742.

Cockerill, Franklin R.; et al. (2012). Methods for Dilution Antimicrobial Susceptibility Tests for Bacteria That Grow Aerobically; Approved Standard-Ninth Edition. CLSI. p. 12

Euzéby, J.P. (2008). Genus Streptomyces. List of Prokaryotic names with Standing in Nomenclature. Retrieved 2008-09-28.

Hughes; C.; Prieto-Davo; A.; Jensen; P.R. and Fenical; W. (2008). Themarynopyrroles; antibiotic of un unprecedented structure class from a marineStreptomyces $s p$. Org Lett 10:629-631.

Khucharoenphaisan, K., N. Sripairoj and K. Sinma, (2012).Isolation and identification of actinomycetes from termite's gut against human pathogen. Asian J.Anim.Vet.Adv.,7:68-73.

Korn-Wendisch, F. and Kutzner, H. J. (1992). The family Streptomycetaceae. In: Balows, A.; Truper, HG.;Dworkin, M.; Harder, W. and Schleifer, KH. (eds), The prokaryotes, Springer-Verlag, New York, 921- 995. 
Kumar, P.; Preetam, R. J.; Duraipandiyan, V. and Ignacimuthu, S. (2012). Antibacterial activity of some actinomycetes from Tamil Nadu, India. Asian Pac J Trop Biomed. 2(12): 936943.

Kumari, K.K., P. Ponmurugan and N. Kannan, 2006.Isolation and characterization of Streptomyces sp. For secondary metabolite production. Biotechnology, 5: 478-480.

Macfaddin, J. F. (2000). Biochemical tests for identification of medical bacteria (3rd ed.), Lippincott Williams and wilkins, U.S.A.

Madigan, M. and Martinko, J. (2005). Brock Biology of Microorganisms (11thed.). Prentice Hall.

Oskay, M.; Tamer, U. A. and Azeri, C. (2004). Antibacterial activity of some actinomycetes isolated from farming soils of Turkey. Afr. J. Biotechnol., 3: 441-446.

Parungao M. M., Maceda E. B. G., Villano M. A. F. (2007). Screening of antibiotic producing actinomycetes from marine, brackish and terrestrial sediment of Samal Island, Philippines. J. Res. Sci. Comput. Eng. 4 29-38.

Prauser, H. (1964) Aptness and application of colour for exact description ofcolours of Streptomyces.Zeitschriftfürallg emeine Mikrobiologie, 4: 95-98.

Qasim B and Risan M. H. (2017). Antitumor and Antimicrobial Activity of Antibiotic Produced by Streptomyces spp, World Journal of Pharmaceutical Research, 6(4):116-128.

Raja, A. and Prabakarana, P. (2011). Actinomycetes and Drug- An overview. Amer J of Drug Disco and Devel.1(2): 75-84.

Ravel, J.; Wellington, E. M. and Hill, R. T. (2000). Interspecific Transfer of Streptomyces Giant Linear Plasmids in Sterile Amended Soil Microcosms.Appl.
Envir. Micro.66: 529-534.

Risan M. H. ; Amin SM, Abdulmohimin N. (2016). Production, Partial Purification and Antitumor Properties of Bioactive Compounds from Locally Isolated Actinomycetes (KH14), Iraqi Journal of Biotechnology, 15(3):51- 64.

Risan M. H. ; Qasim B ; Abdel-jabbar B ; Muhsin A. H. (2017). Identification Active Compounds of Bacteria Streptomyces Using High-Performance Liquid Chromatography, World Journal of Pharmaceutical and Life Sciences, 3(6):91-97.

Risan M. H. ; Taemor S. H . ; Muhsin, A. H. ; Saja M. Hafied; Sarah H. Ghayyib; Zahraa H. Neama (2018). Activity of Lactobacillus acidophilus, $L$. Planetarium, Streptomyces and Saccharomyces cerevisiae with extracts of date palm and dried shell of pomegranate to reduce aflatoxin M1 in Iraq, World Journal of Pharmaceutical and life sciences, 4(6): 119-131

Risan, M. H. ; Rusul J. and Subhi, S. A. (2019). Isolation, characterization and antibacterial activity of a Rare Actinomycete: Saccharopolyspora sp. In Iraq. East African Scholars Journal of Biotechnology and Genetics, 1(4):60-49

Sakiyama, Y; Giang, N. M; Miyadoh, S; Luong, D. T; Hop, D. V; Ando, K (2014). Streptomyces catbensis sp. nov., isolated from soil". International Journal of Systematic and Evolutionary Microbiology. 64 (Pt 6): 2146-51

Shirling E. B and Göttlieb D.( 1966). Methods for characterization of Streptomyces species. Int J Syst Bacteriol;16:313- 40.

Singh, D. and Agrawal, V. P. (2003). Microbial Biodiversity of Mount Sagarmatha Region.In Proceedings of International Seminar on MountainsKathmandu, March 6 - 8, Kathmandu. Nepal Academy of Science andTechnology, Khumaltar, Lalitpur, 
Nepal, 357-360.

Vijayalakshmi, M.; Sujatha S. and Kavitha, A. (2011). Isolation, Identification and Antibacterial Profile of Two Marine Actinobacteria. J Pharm. Res. (7):23172321.

Williams, S.T.; Goodfellow, M.; Alderson, G.; Wellington, E.M.H.; Sneath, P.H.A. and Sackin, M.J. (1983). Numerical classification of Streptomyces and related genera. J. Gen. Microbiol. 129:1743-1813

Williams, S.T.; Locci, R.; Beswick, A.; Kurtböke, D.I.; Kuznetsov, V.D.; Le Monnier, F.J.; Long, P.F.; Maycroft, K.A.; Palmit, R.A.; Petrolini, B.; Quaroni, S.; Todd, J.I. and West, M. (1993). Detection and identification of novel actinomycetes. Rese. in Microbi. 144: 653-656.

\section{How to cite this article:}

Bayader Abdel Mohsen, Mohsen Hashim Risan and Asma G. Oraibi. 2019. Study the Inhibitory Effect of Streptomyces spp against the Growth some Pathogenic Bacterial. Int.J.Curr.Microbiol.App.Sci. 8(12): 270-283. doi: https://doi.org/10.20546/ijcmas.2019.812.038 